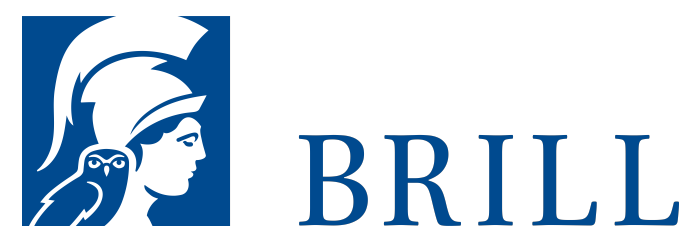

\title{
Family archive from Tebtunis (P. fam.
} Tebt.)

Author: van Groningen

Language:

English

Subjects:

General,

Classical Studies

Publisher: Brill

Series:

Papyrologica

Lugduno-

Batava, Volume:

6

E-Book (PDF)

Released online:

$\mathrm{O} 2 \mathrm{Mar} 2 \mathrm{O} 2 \mathrm{O}$

ISBN: $978-90-$

04-42996-3

List price

USD $\$ 42.00$

Hardback

Publication date:

o1 Dec $195^{\circ}$

ISBN: $978-90-$

04-42881-2 
For more information see brill.com

Order information: Order online at brill.com +44330 333 0049 | customerservices@brill.com Submission information: brill.com/authors

Titles published by Brill | Fink, Brill | mentis or Brill | Schöningh: +49(o)715413279216| brill@brocom.de 